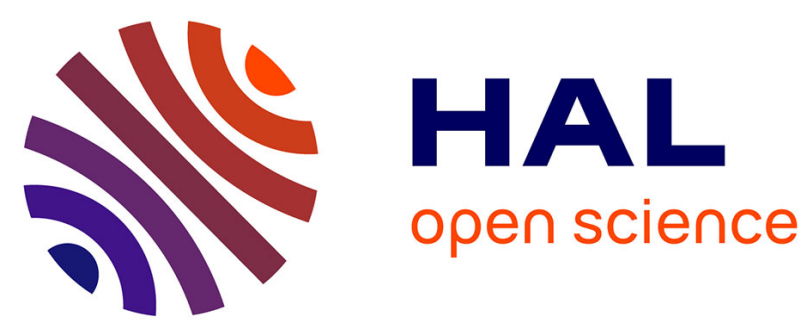

\title{
In situ infrared spectroscopic study of uranium oxides during UO3 carboreduction
}

\author{
Florence Poncet, Françoise Valdivieso, Raymonde Gibert, Michèle Pijolat
}

\section{To cite this version:}

Florence Poncet, Françoise Valdivieso, Raymonde Gibert, Michèle Pijolat. In situ infrared spectroscopic study of uranium oxides during UO3 carboreduction. Eurosolid 4: European conference on transformation kinetics and reactivity of solids, Sep 1997, Saint Vincent, Italy. pp.151-157. emse00614946

\section{HAL Id: emse-00614946 \\ https://hal-emse.ccsd.cnrs.fr/emse-00614946}

Submitted on 17 Aug 2011

HAL is a multi-disciplinary open access archive for the deposit and dissemination of scientific research documents, whether they are published or not. The documents may come from teaching and research institutions in France or abroad, or from public or private research centers.
L'archive ouverte pluridisciplinaire HAL, est destinée au dépôt et à la diffusion de documents scientifiques de niveau recherche, publiés ou non, émanant des établissements d'enseignement et de recherche français ou étrangers, des laboratoires publics ou privés. 


\title{
In situ infrared spectroscopy study of uranium oxides during $\mathrm{UO}_{3}$ carboreduction
}

\author{
F. PONCET, F. VALDIVIESO, R. GIBERT and M. PIJOLAT \\ Centre SPIN, Ecole des Mines, 158 cours Fauriel \\ 42023 Saint-Etienne, Cedex 2 FRANCE.
}

\begin{abstract}
:
Carboreduction of $\mathrm{UO}_{3}$ has been studied by in situ infrared spectroscopy in order to detect the presence of carbon monoxide during the reduction. From thermogravimetry, the reaction was observed to occur in two steps : (i) reduction of $\mathrm{UO}_{3}$ to $\mathrm{U}_{3} \mathrm{O}_{8}$ by carbon at $440^{\circ} \mathrm{C}$ and (ii) reduction at $590^{\circ} \mathrm{C}$ of $\mathrm{U}_{3} \mathrm{O}_{8}$ to $\mathrm{UO}_{2}$ by carbon. No carbon monoxide was observed during the reaction. Nevertheless, formation of carboxylate species are observed at temperature below $550^{\circ} \mathrm{C}$ with absorption bands at 1017 and $1300 \mathrm{~cm}^{-1}$.
\end{abstract}

\section{1- Introduction}

Reduction of uranium trioxide by carbon was carried out in order to obtain uranium dioxide, intermediate currently used for the preparation of nuclear combustible.

According to the literature [1], the carboreduction of $\mathrm{UO}_{3}$ to $\mathrm{UO}_{2}$ is proceeds in two stages (1) the conversion of $\mathrm{UO}_{3}$ to $\mathrm{U}_{3} \mathrm{O}_{8}$ and (2) the reduction of $\mathrm{U}_{3} \mathrm{O}_{8}$ to $\mathrm{UO}_{2}$ by reaction with carbon. Nevertheless, the mechanism of reduction of $\mathrm{U}_{3} \mathrm{O}_{8}$ to $\mathrm{UO}_{2}$ still controversy. In fact, some authors like Lawrance and O'Connor [2] reported that during the reduction, a mixture of carbon monoxide and carbon dioxide is evolved. So, for some authors [3] a fraction of the carbon monoxide contribute to the reduction of $\mathrm{U}_{3} \mathrm{O}_{8}$. Whereas for Mukerjee et al. [4], which found only carbon dioxide in the gas product, the reduction is only due to the carbon.

To elucidate this difference and in order to better know the reactionnal intermediates during the carboreduction, we have performed the reduction of $\mathrm{UO}_{3}$ by thermogravimetric analysis (TGA) and in situ infrared spectroscopy.

Our aim was to look for the presence or not of carbon monoxide at the uranium oxide surface during the transformation. According to the literature [5], adsorption of carbon monoxide on oxides produces absorption bands in the region of $2100-2000 \mathrm{~cm}^{-1}$.

\section{2 - Experimental results}

\section{2-1 Thermogravimetric analysis}

Thermogravimetric study was performed in a SETARAM TAG 24 thermobalance equipped with a BALZERS mass spectrometer for the analysis of the evolved gases. The sample used was a powder resulting from the mixture with a slight manual grinding of $\beta$-phase uranium trioxide with an excess of carbon (in a 
$\mathrm{C} / \mathrm{U}=3$ mole ratio). The sample size in each experiment is $28 \mathrm{mg}$. The reaction occurs under two liters per hour of flowing helium with a $5^{\circ} \mathrm{C} / \mathrm{min}$ heating rate up to $900^{\circ} \mathrm{C}$.

Figure 1 show the results of the thermogravimetric analysis and figure 2 gives the analysis of the evolved gas during heating.

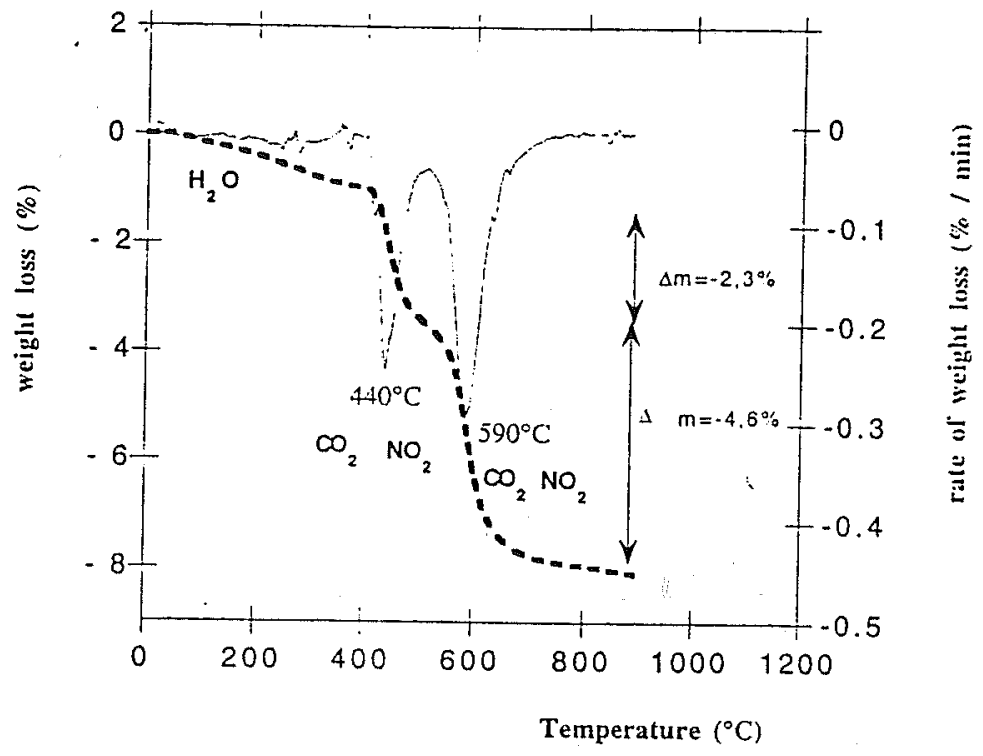

Figure 1 : Curves of weight loss (\%) and rate of weight loss (\%:min) versus temperature $\left({ }^{\circ} \mathrm{C}\right)$

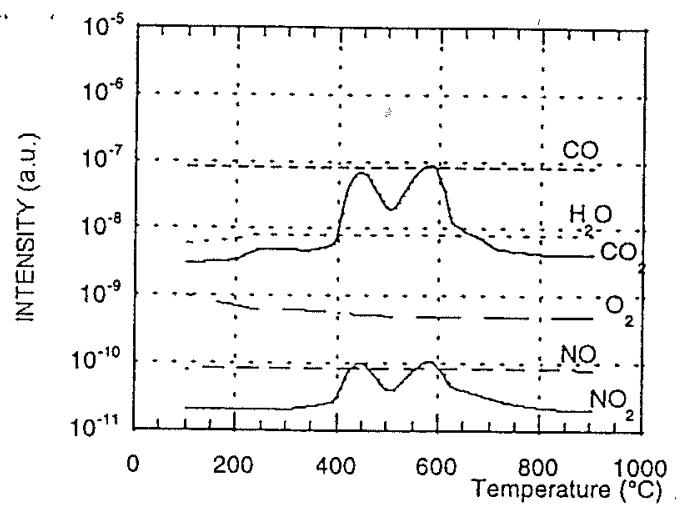

Figure 2 : Gas evolving followed by mass spectrometer during heating, arbitrary unit versus temperature $\left({ }^{\circ} \mathrm{C}\right)$ 
We can notice principally on the figure 1 two successive steps in weight loss, whose the maximun rates occur at 440 and $590^{\circ} \mathrm{C}$. These weight losses, respectively 2.3 and $4.6 \%$ are accompanied by emission of nitrogen dioxide and essentially carbon dioxide (figure 2). The nitrogen dioxide is two order magnitude less in intensity than carbon dioxide. So, the nitrogen dioxide does not contribute to the weight loss. A small weight loss, inferior to $1 \%$, is appearing between room temperature and $200^{\circ} \mathrm{C}$, is only due to the desorption of water.

The weight loss observed at $440^{\circ} \mathrm{C}(2.3 \%)$, is equivalente to the theoretical weight loss calculated for the reduction of $\mathrm{UO}_{3}$ to $\mathrm{U}_{3} \mathrm{O}_{8}$ by carbon from the initial mass of the mixture, according to (1):

$$
3 \mathrm{UO}_{3}+1 / 2 \mathrm{C} \rightarrow \mathrm{U}_{3} \mathrm{O}_{8}+1 / 2 \mathrm{CO}_{2}
$$

The weight loss observed at $590^{\circ} \mathrm{C}(4.6 \%)$ is due to the reduction by carbon of the intermediate oxide $\mathrm{U}_{3} \mathrm{O}_{8}$ to $\mathrm{UO}_{2}$ (theoretical value calculated from initial mass of mixture is $4.66 \%$ ), according to (2):

$$
\mathrm{U}_{3} \mathrm{O}_{8}+\mathrm{C} \rightarrow 3 \mathrm{UO}_{2}+\mathrm{CO}_{2}
$$

A complementary analysis by X-ray diffraction of the samples obtained at an intermediate step $\left(450^{\circ} \mathrm{C}\right)$ and at the end of the heating $\left(900^{\circ} \mathrm{C}\right)$ confirms the formation of the compound $\mathrm{U}_{3} \mathrm{O}_{8}$ and the uranium dioxide, respectively.

\section{2-2 In-situ infrared analysis}

The results of in situ infrared analysis are given in figures 3,4 and 5. In situ infrared spectra have been carried out under flowing argon by means of a FTIR Bio-Rad spectrometer equipped with a high temperature environmental chamber (HTEC) model 0030-103 of Spectra Tech.

The infrared spectra are obtained using diffuse reflectance. A complete scan from 4000 to $400 \mathrm{~cm}^{-1}$ is given in transmittance in figures 3 and 4 . The maximum transmittance is observed between 1000 to $400 \mathrm{~cm}^{-1}$, so a detailed scan in KubelkaMunk is shown figure 5 in this region. 


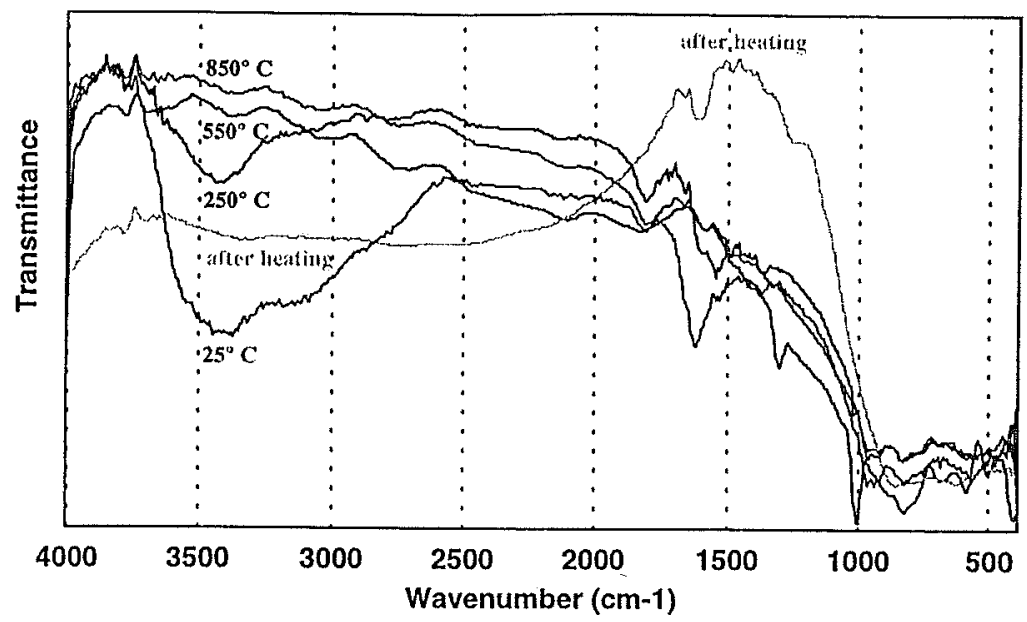

Figure 3: In situ FTIR spectra of $\mathrm{UO}_{3}$ and $\mathrm{C}$ mixture under argon in range of 4000 to $400 \mathrm{~cm}^{-1}$ at various temperatures

At room temperature and until $350^{\circ} \mathrm{C}$ (figure 3), the infrared spectra show absorption bands at 1640 and above $3000 \mathrm{~cm}^{-1}$. These bands disappear during heating, they are due to the presence of adsorbed water and are assigned respectively to the bending and stretching symmetric and asymmetric vibrations of $\mathrm{H}_{2} \mathrm{O}$ molecule.

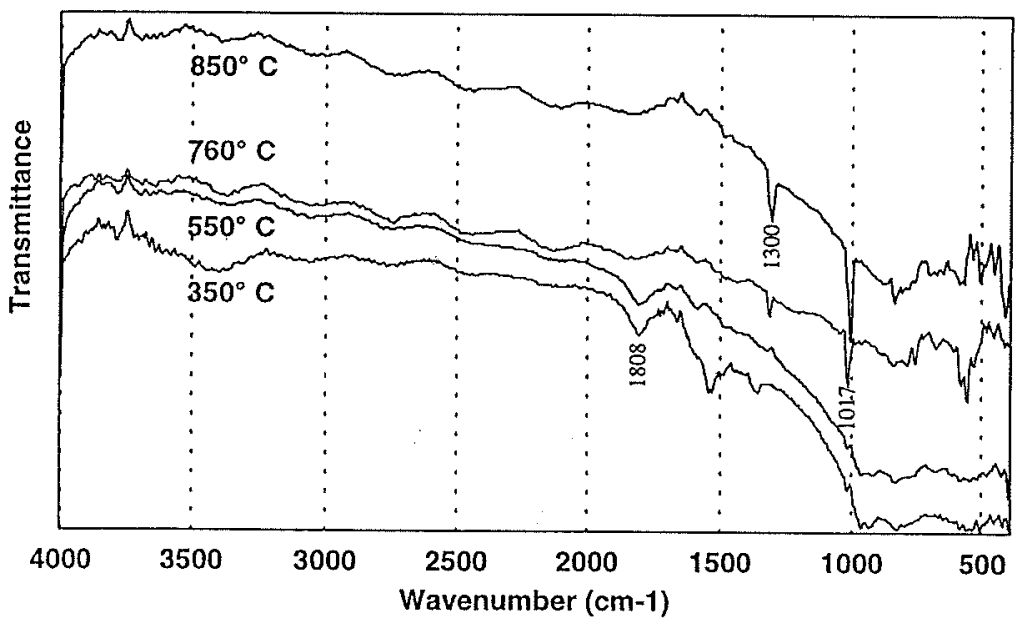

Figure 4: In situ FTIR spectra of $\mathrm{UO}_{3}$ and $\mathrm{C}$ mixture under argon in range of 4000 to $400 \mathrm{~cm}^{-1}$ at various temperatures 
The figure 4 shows also a band at $1800 \mathrm{~cm}^{-1}$ between room temperature and $550^{\circ} \mathrm{C}$. This band is accompanied by bands in the region of $900 \mathrm{~cm}^{-1}$. When the temperature raised up $550^{\circ} \mathrm{C}$, the spectra change drastically with disappearance of the bands at 1800 and $900 \mathrm{~cm}^{-1}$ to give bands at 1300 and $1017 \mathrm{~cm}^{-1}$ and a slight shift in lower wavenumber of the bands at $900 \mathrm{~cm}^{-1}$. After cooling the sample at room temperature (figure 3 ), the bands at 1300 and $1017 \mathrm{~cm}^{-1}$ disappear.

In order to understand the behavior of our solid during heating, we have represented figure 5 the infrared spectra results in the region of the solid frequencies vibration (1000 to $400 \mathrm{~cm}^{-1}$ ) in Kubelka-Munk.

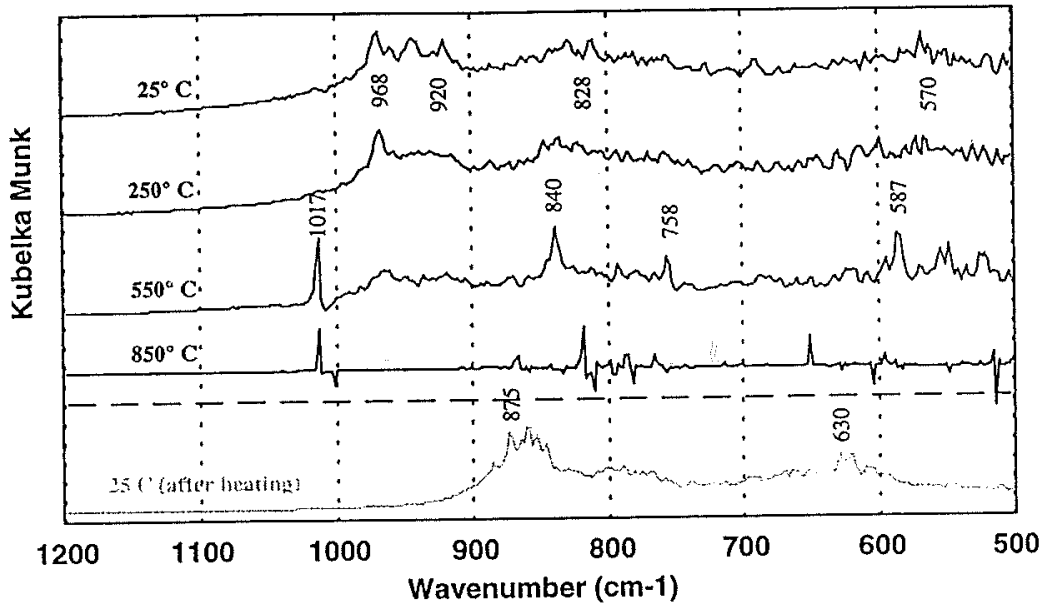

Figure 5 : In situ FTIR spectra of $\mathrm{UO}_{3}$ and $\mathrm{C}$ mixture under argon in range of 1200 to $500 \mathrm{~cm}^{-1}$ at various temperatures

At room temperature and until $350^{\circ} \mathrm{C}$ (figure 5), the absorption bands observed at $570-828-920$ and $968 \mathrm{~cm}^{-1}$ are assigned to the absorption bands of $\beta-\mathrm{UO}_{3}$, according to the literature [6-8]. From $450^{\circ} \mathrm{C}$ to $760^{\circ} \mathrm{C}$, infrared spectra change with a decrease in absorption bands at 968 and $920 \mathrm{~cm}^{-1}$ and the appearance of an absorption band at $758 \mathrm{~cm}^{-1}$. This band is assigned to the U-O streching vibration of the uranium octoxide $\mathrm{U}_{3} \mathrm{O}_{8}$. At $850^{\circ} \mathrm{C}$ and after cooling a broad absorption band is observed around $875 \mathrm{~cm}^{-1}$ which was interpreted by Colmenares [9] as an optical phonon frequency of $\mathrm{UO}_{2}$ phase.

\section{3 - Discussion and conclusion}

Consequently, carboreduction of $\mathrm{UO}_{3}$ occurs in two steps : (1) reduction of uranium trioxide in uranium octoxide at $440^{\circ} \mathrm{C}$ by carbon and (2) reduction at $590^{\circ} \mathrm{C}$ of $\mathrm{U}_{3} \mathrm{O}_{8}$ in uranium dioxide by carbon. The main gas observed during carboreduction is carbon dioxide. We can note (figure 2 ) the end of carbon dioxide 
emission around $700^{\circ} \mathrm{C}$, the carboreduction of $\mathrm{U}_{3} \mathrm{O}_{8}$ in uranium dioxide is probably finished at this temperature.

During in situ infrared analysis we have reduced the $\mathrm{UO}_{3}$ in $\mathrm{UO}_{2}$ via $\mathrm{U}_{3} \mathrm{O}_{8}$ at the same temperature range as thermogravimetric analysis. But, no absorption band is observed in the region of $2000-2200 \mathrm{~cm}^{-1}$, we can see only an absorption band at $1880 \mathrm{~cm}^{-1}$ between 25 to $550^{\circ} \mathrm{C}$, this band is assigned to the harmonic of the absorption band at $920 \mathrm{~cm}^{-1}$. Consequently, carbon monoxide was not observed which is in agreement with the reactions (1) and (2).

However the presence of the bands at 1017 and $1300 \mathrm{~cm}^{-1}$ at temperature below $550^{\circ} \mathrm{C}$ is probably due to the chemisorbed carboxylate on the uranium oxyde surface. According to the litterature [5], carboxylate adsorbed on oxides $\left(\mathrm{CO}_{3}{ }^{-}\right)$ display absorption bands in the region : $1090-1020 \mathrm{~cm}^{-1}$ and $1450-1420 \mathrm{~cm}^{-1}$. The formation of carboxylate may be explained by the presence of gaseous carbon dioxide observed previously by thermogravimetry during the carboreduction. 
[1] Joseph J. Katz and Eugene Rabinowitch, The chemistry of uranium, Part.1. Element, its binary and related compounds, Mc graw Hill (1951).

[2] J.J. Lawrence and D.J. O'Connor, J. Nucl. Mater., vol.4 (1961) 79.

[3] V.G. Vlasov, E.V. Tkachenko, Zhurnal Prikladnoi Khimiiog, 37 (1964) 946.

[4] S.K. Mukerjee, G.A. Rama Rao, J.V. Dehadraya, V.N.Vaidya, V. Venugopal and D.D. Sood, J. Nucl. Mater. 199 (1993) 247.

[5] A.A. Davydov, Infrared spectroscopy of adsorbed species on the surface of transition metals oxides, edited by C.H. Rochester John Wiley \& Sons (1990)

[6] Geoffrey .C. Allen and Nigel R. Holmes, Applied spectroscopy, vol 48, number 4 (1994) 525.

[7] H. R. Hoekstra and S. Siegel, J. Inorg. Chem.,vol. 18 (1961) 154.

[8] M. Tsuboi, M. Terada and T. Shimanouchi, J. Chem. Phys., vol 36, number 5 (1962) 1301.

[9] C. colmenares, J. Phys. Chem., vol 78, number 21 (1974) 2117. 